\title{
TINGKAT LABA PADA UD. AZKA JATI JEPARA KUPANG
}

\author{
Oleh : \\ Mesri Nubatonis *, Jennie S.Sir **
}

\begin{abstract}
Abstrak:
Modal kerja merupakan masalah pokok yang seringkali dihadapi oleh perusahaan, karena hampir semua perhatian untuk mengelola modal kerja dan aktiva lancar merupakan bagian yang cukup besar dari aktiva. Modal kerja dibutuhkan oleh setiap perusahaan untuk membelanjai operasinya sehari-hari.Berdasarkan pembahasan dan analisa yang telah ditemukakan, dapat diambil kesimpulan bahwa tingkat perputaran modal kerja yang dicapai oleh UD. Azka Jati Jepara Kupang pada tahun 2012-2014. Pada tahun 2012 perputaran kas 2,6 kali peputaran piutang 7,5 kali dan perputaran persediaan 3,50 kali. Pada tahun 2013 perputaran kas 7,5 kali perputan piutang 12,5 kali dan perputaran persediaan 15,9 kali sedangkan pada tahun 2014 perputaran kas 2,48 kali perputaran piutang 5,95 kali dan perputaran persediaan 2,41 kali. Hal ini menunjukan bahwa modal kerja pada UD. Azka Jati Jepara Kupang belum dapat dikatakan efisien karena perusahaan berfluktuasi dari tahun ke tahun. Tingkat profitabilitas yang dicapai oleh UD. Azka Jati Jepara Kupang pada tahun 2012-2014. Pada tahun 2012 ROI 359\% tahun 2013 272\% sedangkan tahun 2014 201\%. Hal ini menunjukan bahwa efktifitas dan efisien dalam tingkat profitabilitas pada perusahaan sudah tercapai. Penilaian perputaran modal kerja dan tingkat profitabilitas yang dicapai oleh UD. Azka Jati Jepara Kupang pada tahun 2012-2014. Pada tahun 2012 perputaran kas 2,6 kali hal ini menunjukan bahwa perputaran kas cukup sehat.
\end{abstract}

Kata Kunci : Pengelolaan, Modal kerja, Laba

*)Mesri Nubatonis : Alumni Mahasiswa Program Studi Akuntansi Sektor Publik Politeknik Negeri Kupang.

**) Jennie S.Sir; Dosen Program Studi Akuntansi Sektor Publik Politeknik Negeri Kupang.

\section{PENDAHULUAN}

Pembangunan di Bidang Ekonomi terdiri dari tiga sektor usaha nasional yaitu usaha Pemerintah, usaha swasta dan Koperasi. Di era perkembangan yang makin pesat ini usaha swasta semakin meningkat, teknologi kemampuan menejerial mampu menghasilkan barang maupun jasa guna memenuhi kebutuhan masyarakat. Disamping itu usaha swasta dapat juga menciptakan lapangan kerja baru, dengan demikian berkembangnya dunia usaha dewasa ini, persaingan antara perusahaan khususnya antar perusahaan yang sejenis akan semakin ketat, untuk menjaga kelangsungan hidup perusahaan dalam menghadapi persaingan yang ketat 
tersebut, maka di perlukan suatu penanganan dan pengelolaan sumber daya yang di lakukan oleh pihak manajemen dengan baik. Bagi pihak manajemen, selain dituntut untuk dapat mengkoordinasi penggunaan seluruh sumber daya yang di miliki oleh perusahaan secara efektif dan efisien, juga di tuntut untuk dapat menghasilkan keputusan-keputusan yang menunjang terhadap pencapaian tujuan perusahaan di masa yang akan datang.

Modal kerja merupakan masalah pokok dan topik penting yang seringkali dihadapi oleh perusahaan, karena hampir semua perhatian untuk mengelola modal kerja dan aktiva lancar merupakan bagian yang cukup besar dari aktiva. Modal kerja dibutuhkan oleh setiap perusahaan untuk membelanjai operasinya sehari-hari, misalnya untuk pembelian bahan mentah, membiayai upah gaji karyawan, dan lainlain, dimana uang atau dana yang dikeluarkan tersebut diharapkan dapat kembali lagi masuk dalam perusahaan dalam waktu singkat melalui hasil penjualan produksinya. Oleh karena itu, perusahaan dituntut untuk selalu meningkatkan efisiensi kerjanya sehingga dicapai tujuan yang diharapkan oleh perusahaan yaitu mencapai laba yang optimal.

Laba adalah salah satu faktor yang penting dalam mempengaruhi kemajuan dan kemunduran suatu perusahaan. Artinya, meningkatkan laba berarti meningkatkan kesejahteraan pada perusahaan tersebut. Jika perusahaan tersebut dapat meningkatkan laba secara optimal, maka akan terjadi penambahan modal kerja. Sebaliknya, jika perusahaan tidak dapat meningkatkan laba secara optimal, maka terjadi pengurangan modal kerja.

Perusahaan akan selalu berusaha mencapai laba yang optimal secara efisien dan efektif serta berusaha mempertahankan kelangsungan hidup perusahaan. Adapun cara perusahaan meningkatkan laba yaitu dengan cara meningkatkan volume penjualan, menaikkan harga penjualan dan mengurangi biaya. Proses dalam pencapaian laba tersebut membutuhkan ketersediaan dana atau modal kerja yang cukup untuk membeli aktiva tetap, membeli persediaan barang jadi, membayar gaji karyawan, dan untuk kepentingan transaksi perusahaan maupun untuk menjaga likuiditas perusahaan. Dana yang dibutuhkan oleh perusahaan bersumber dari pemilik perusahaan (modal sendiri) maupun modal dari pinjaman (hutang jangka panjang).

Agar tetap dapat survive, maka perusahaan harus bisa melakukan efisiensi untuk menekan biaya agar dapat mengimbangi keuntungan dan mengurangi kerugian. Kemampuan menghasilkan output yang maksimal dengan input yang ada, adalah merupakan ukuran kinerja yang diharapkan.

Modal kerja memiliki sifat yang fleksibel, besar kecilnya modal kerja dapat ditambah atau dikurangi sesuai kebutuhan perusahaan. Menetapkan modal kerja yang terdiri dari kas, piutang, dan persediaan harus dimanfaatkan seefisien mungkin. 
Besarnya modal kerja harus sesuai dengan kebutuhan perusahaan, karena baik kelebihan atau kekurangan modal kerja sama-sama membawa dampak negatif bagi perusahaan. Dengan kata lain, modal kerja yang cukup akan dapat memberikan keuntungan yang maksimal.

Dalam suatu perusahaan, pengelolaan modal kerja merupakan hal yang sangat penting juga, karena meliputi pengambilan keputusan mengenai jumlah dan komposisi aktiva lancar dan bagaimana membiayai aktiva ini. Perusahaan yang tidak dapat memperhitungkan tingkat modal kerja yang memuaskan, maka perusahaan kemungkinan mengalami insolvency (tidak mampu memenuhi kewajiban jatuh tempo) dan bahkan mungkin terpaksa harus di likuidasi. Aktiva lancar harus cukup besar untuk dapat menutup hutang lancar sedemikian rupa, sehingga menggambarkan adanya tingkat keamanan (margin safety) yang memuaskan. Sementara itu, jika perusahaan menetapkan modal kerja yang terlalu besar dari yang dibutuhkan akan mengakibatkan terjadinya dana yang menganggur, sehingga tidak efisien dalam penggunaan dana. Sebaliknya, jika perusahaan menetapkan modal kerja yang lebih kecil dari kebutuhan, akan menimbulkan kerugian atau kehilangan kesempatan untuk memperoleh laba.

Pengelolaan modal kerja yang baik merupakan tanggung jawab setiap pimpinan perusahaan, sehingga dalam setiap penggunaan modal kerja perusahaan dapat tercapai suatu keseimbangan dalam hal penyediaan dan penggunaan modal kerja tersebut. Kebanyakan perusahaan menempuhnya melalui kebijakan peningkatan omzet penjualan, baik perusahaan jasa, perusahaan perdagangan dan perusahaan manufaktur. Hal ini terlihat dari perencanaan yang disusun sebagian perusahaan dari tahun ke tahun, peningkatan pembuatan pemesanan akan selalu menjadi prioritas utama perusahaan untuk meningkatkan laba.

Oleh sebab itu, minimnya modal kerja, maka dalam melakukan kegiatan suatu perusahaan tidak akan sesuai dengan rencana maka akan timbul beberapa hal diantaranya: Tidak tercapainya laba yang ditarget, kebutuhan konsumen tidak terpenuhi karena kekurangan modal maka kegiatan lain tidak terlaksana. Secara khusus penelitian ini dimaksudkan supaya laporan keuangan dapat memberikan informasi mengenai pengelolaan modal kerja.

UD Azka Jati Jepara merupakan suatu perusahaan yang bergerak dibidang meubel dimana selain menjual peralatan meubel, perusahaan ini juga termasuk sebagai perusahaan yang mengelola bahan baku menjadi barang jadi seperti lemari, meja, kursi, tempat tidur, dan peralatan meubel lainnya sesuai apa yang dipesan konsumen dan dalam proses produksi meubel ini dihasilkan berdasarkan pesanan dan proses produksi secara terus-menerus tanpa melihat adanya pesan dari konsumen guna mengisi persediaan yang akan dijual. Perusahaan beralamat di Jl. Bimoku km 12 Kelurahan Lasiana Kecamatan Kelapa Lima, Kupang NTT. Dengan berjalannya 
waktu UD. Azka Jati Jepara mengalami peningkatan modal kerja. Hal tersebut terjadi karena semakin meningkatnya jumlah produksi dan penjualan hasil produksi.

UD. Azka Jati Jepara dalam menjalankan kegiatan operasional usahanya tentunya harus selalu memperhatikan hal-hal yang mempengaruhi peningkatan laba dan kemajuan usahanya. Selama ini UD. Azka Jati Jepara telah membuat laporan keuangan setiap tahunnya dan dari laporan keuangan tersebut dapat diketahui sebagai elemen-elemen yang mempengaruhi modal kerja dan tingkat labanya.

Berikut ini adalah kondisi modal kerja, perusahaan dari tahun 2012, 2013 dan 2014 adalah sebagai berikut:

\section{Perbandingan Jumlah Modal Kerja, Pendapatan Dan Laba Operasi Dari Tahun 2012, 2013 Dan 2014}

\begin{tabular}{|l|c|c|c|c|c|}
\hline \multirow{2}{*}{ Keterangan } & \multicolumn{3}{|c|}{ Tahun } & \multicolumn{2}{c|}{ Modal Kerja 2012-2014 } \\
\cline { 2 - 6 } & $\mathbf{2 0 1 2}(\mathbf{R p})$ & $\mathbf{2 0 1 3}(\mathbf{R p})$ & $\mathbf{2 0 1 4}(\mathbf{R p})$ & \multicolumn{2}{c|}{ Naik / Turun } \\
\hline Modal Kerja & 300.000 .000 & 660.000 .000 & 920.000 .000 & 100.000 .000 & 50.000 .000 \\
\hline pendapatan & 100.000 .0000 & 460.000 .000 & 595.000 .000 & 360.000 .000 & 135.000 .000 \\
\hline Laba Bersih & 127.500 .000 & 144.500 .000 & 127.500 .000 & 17.000 .000 & $(17.000 .000)$ \\
\hline
\end{tabular}

\section{Sumber : UD. Azka Jati Jepara}

Berdasarkan tabel 1.1 dapat dilihat bahwa jumlah modal kerja, pendapatan dan laba bersih pada tahun 2014 meningkat dari tahun sebelumnya. Namum mengenai modal kerja dan tingkat labanya masih perlu diananalisis lebih lanjut, apakah efisien dalam penggunaannya, karena peningkatan yang terjadi pada pendapatan juga ikuti dengan peningkatan aktiva perusahaan. Disamping itu perusahaan dituntut untuk selalu meningkatkan efisiensi kerjanya sehingga mencapai tujuan yang diharapkan, efisiensi baru dapat diketahui dengan membandingkan laba yang diperoleh dengan aktiva yang menghasilkan laba tersebut. Oleh sebab itu maka penulis sangat tertarik untuk melakukan penelitian dengan judul "ANALISIS PENGELOLAAN MODAL KERJA TERHADAP TINGKAT LABA PADA UD. AZKA JATI JEPARA Di Kupang".

\section{Rumusan Masalah}

Berdasarkan pada uraian-uraian dalam latar belakang di atas, maka masalah pokok yang diidentifikasi dalam penelitian ini adalah : "Apakah pengelolaan modal kerja untuk usaha UD. Azka Jati Jepara dari tahun 2012 sampai dengan tahun 2014 sudah efisien dalam meningkatkan labanya jika ditinjau dengan metode perputaran modal kerja dan rasio profitabilitas." 


\section{Tujuan Penelitian}

Tujuan penelitian dalam penulisan ini adalah untuk mengetahui pengelolaan modal kerja terhadap tingkat laba pada UD. Azka Jati Jepara dari tahun 2012, 2013 dan 2014

\section{KERANGKA BERPIKIR}

Sebagaimana telah di jelaskan bahwa permasalahan dalam penelitian ini adalah analisis pengelolaan modal kerja terhadap tingkat laba bagi perusahaan. Untuk menjawab pertanyaan ini, tentunya tidak terlepas dari peran modal kerja. Dan untuk dapat mengelolanya, dibutuhkan kebijaksanaan dan strategi yang tepat, apabila hal tersebut dapat ditetapkan secara baik dan efisien maka laba yang ditargetkan dapat tercapai dengan baik. Secara singkat kerangka pemikiran ini dapat dituangkan dalam gambar di bawah ini:

Gambar 1

Kerangka Berpikir

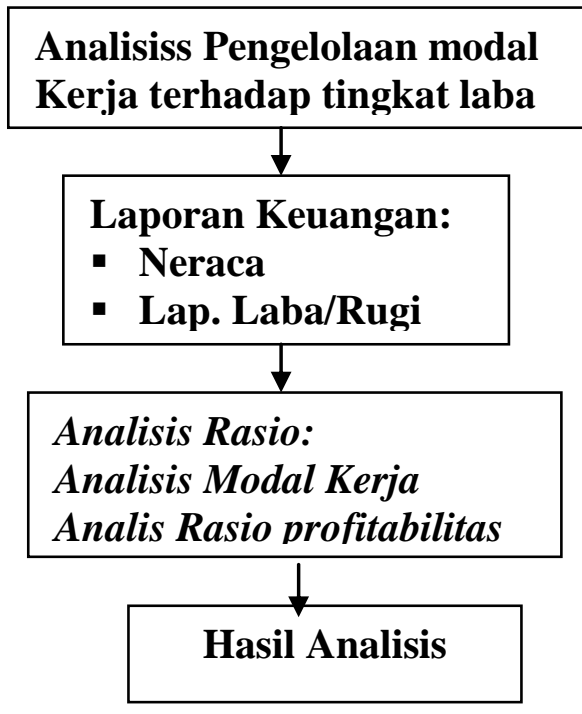

\section{Hipotesis}

"Hipotesis adalah sebuah kesimpulan tetapi kesimpulan tersebut belum final, dan masih harus dibuktikan kebenarannya. Jelas sekali pernyataan diatas tersebut bahwa hipotesis adalah suatu pernyataan terhadap suatu hal yang bersifat sementara dan harus dibuktikan kebenarannya melalui suatu penelitian.

Berdasarkan pada pengertian diatas, maka penulis mengajukan hipotesis terhadap penelitian yang akan dilakukan yaitu analisis pengelolaan modal kerja terhadap tingkat laba jika modal kerja dikelola secara baik, maka laba yang diperoleh perusahaan dapat meningkat.

\section{METODE PENELITIAN}

Berdasarkan lokasi penelitian di atas maka yang menjadi objek penelitian dalam penulisan ini adalah Analisis Pengelolaan Modal Kerja Terhadap Tingkat Laba pada perusahaan yang sesuai dengan keadaan yang sebenarnya, sehingga dapat memberikan gambaran yang cukup jelas atas obyek yang diteliti. Jenis Data Berdasarkan data dan keterangan yang dikumpulkan penulis, maka jenis data yang di gunakan dalam penelitian ini adalah: Data kuantitatif dan data kualitatif. Sumber data yang digunakan dalam penelitian ini adalah: Data Primer dan Data Sekunder. Metode analisis yang dapat digunakan penulis dalam penelitian ini adalah deskriptif kuantitatif, yang berupa angka. Maka analisis yang digunakan adalah analisis perputaran modal kerja dan rasio profitabilitas. 
HASIL PENELITIAN

\section{PEMBAHASAN}

\section{Analisis Hasil Penelitian}

Modal kerja adalah investasi perusahaan dalam jangka pendek yang melekat pada aktiva lancar seperti kas, surat-surat berharga, piutang dan persediaan. Ada tiga konsep umum yang dipergunakan yaitu konsep kuantitatif, konsep kualitatif dan konsep fungsional. Dari tiga konsep tersebut, yang sesuai dengan penelitian ini adalah konsep kuantitatif. Konsep ini menitikberatkan kuantum yang diperlukan untuk tujuan

\section{Tabel 6}

Pengukuran Skor

Perputaran Modal Kerja dan Rasio Profitabilitas.

\begin{tabular}{|c|c|c|c|}
\hline No & Rasio & Pengukuran & Skor \\
\hline \multirow{6}{*}{1.} & \multirow{6}{*}{ Perputaran Modal Kerja } & $x>=5$ & 5 \\
\hline & & $\mathrm{x}<=4$ & 4 \\
\hline & & $x<=3$ & 3 \\
\hline & & $x<=2$ & 2 \\
\hline & & $\mathrm{x}<=1$ & 1 \\
\hline & & $\mathrm{x}<=0$ & 0 \\
\hline \multirow{6}{*}{2.} & \multirow{6}{*}{ Return On Infestment (ROI) } & $125>=x$ & 5 \\
\hline & & $110<=\mathrm{x}<125$ & 4 \\
\hline & & $100<=\mathrm{x}<110$ & 3 \\
\hline & & $95<=\mathrm{x}<100$ & 2 \\
\hline & & $90<=x<95$ & 1 \\
\hline & & $x<90$ & 0 \\
\hline
\end{tabular}

Sumber : Kapmen BUMN No. 100 Tahun2001

Setelah mengetahui perhitungan dari segi perputaran modal kerja dan rasio profitabilitas, selanjutnya untuk menilai tingkat kesehatan keuangan dilakukan dengan membandingkan hasil dari perhitungan rasio tersebut dengan skor yang telah ditetapkan, dapat dilihat pada tabel dibawah ini :

Keterangan Skor penilaian perputaran modal kerja sebagai berikut :

Tabel 7

Standar Pengukuran Perputaran Modal Kerja

\begin{tabular}{|c|c|}
\hline Skor & Kriteria \\
\hline 5 & Sangat baik \\
\hline 4 & Baik \\
\hline 3 & Cukup baik \\
\hline 2 & Kurang baik \\
\hline 1 & Tidak baik \\
\hline 0 & Buruk \\
\hline
\end{tabular}




\section{TABEL 8}

NERACA PERBANDINGAN

PER TAHUN 2012, 2013 DAN 2014

\begin{tabular}{|c|c|c|c|c|c|}
\hline Keterangan & Tahun 2012 & Tahun 2013 & Tahun 2014 & $\begin{array}{c}\text { Naik turun } \\
2013-2012\end{array}$ & $\begin{array}{r}\text { Naik turun } \\
2014-2013 \\
\end{array}$ \\
\hline & $(\mathbf{R p})$ & $(\mathbf{R p})$ & $(\mathbf{R p})$ & $(\mathbf{R p})$ & (Rp) \\
\hline $\begin{array}{l}\text { Aktiva Lancar } \\
\text { Kas } \\
\text { Surat-surat Berharga } \\
\text { Piutang Dagang } \\
\text { Persediaan }\end{array}$ & $\begin{array}{l}100.000 .000 \\
150.000 .000 \\
55.000 .000 \\
45.500 .000\end{array}$ & $\begin{array}{r}200.000 .000 \\
150.000 .000 \\
50.000 .000 \\
150.000 .000\end{array}$ & $\begin{array}{c}250.000 .000 \\
175.000 .000 \\
55.000 .000 \\
155.000 .000\end{array}$ & $\begin{array}{c}100.000 .000 \\
- \\
5.500 .000^{*} \\
105.000 .000\end{array}$ & $\begin{array}{l}50.000 .000 \\
25.000 .000 \\
5.000 .000 \\
5.000 .000\end{array}$ \\
\hline Jumlah Aktiva Lanca & 350.500 .000 & 550.000 .000 & 635.000 .000 & 199.500 .000 & 85.000 .000 \\
\hline $\begin{array}{l}\text { Aktiva Tetap } \\
\text { Peralatan } \\
\text { Inventaris Kantor } \\
\text { Gedung } \\
\text { Tanah } \\
\text { Kendaraan }\end{array}$ & $\begin{array}{r}30.000 .000 \\
7.000 .000 \\
15.000 .000 \\
13.000 .000 \\
2.000 .000\end{array}$ & $\begin{array}{c}35.000 .000 \\
10.000 .000 \\
12.000 .000 \\
15.000 .000 \\
3.000 .000\end{array}$ & $\begin{array}{c}50.000 .000 \\
15.000 .000 \\
20.000 .000 \\
20.000 .000 \\
5.000 .000\end{array}$ & $\begin{array}{l}5.000 .000 \\
3.000 .000 \\
3.000 .000 * \\
2.000 .000 \\
1.000 .000\end{array}$ & $\begin{array}{r}15.000 .000 \\
5.000 .000 \\
8.000 .000 \\
5.000 .000 \\
2.000 .000\end{array}$ \\
\hline $\begin{array}{l}\text { Jumlah Aktiva Tetap } \\
\text { TOTAL ATIVA }\end{array}$ & \begin{tabular}{|l|}
67.000 .000 \\
417.500 .000 \\
\end{tabular} & \begin{tabular}{|l|}
75.000 .000 \\
625.000 .000
\end{tabular} & $\begin{array}{l}110.000 .000 \\
745.000 .000\end{array}$ & \begin{tabular}{|l|}
8.000 .000 \\
207.500 .000
\end{tabular} & \begin{tabular}{|c|}
35.000 .000 \\
120.000 .000
\end{tabular} \\
\hline $\begin{array}{l}\text { Hutang Lancar } \\
\text { Hutang Dagang }\end{array}$ & 107.000 .000 & 110.000 .000 & 120.000 .000 & 3.000 .000 & 10.000 .000 \\
\hline Jumlah Hutang Lancar & 107.000 .000 & 110.000.000 & 120.000 .000 & 3.000 .000 & 10.000 .000 \\
\hline $\begin{array}{l}\text { Hutang Jangka Panjang } \\
\text { Hutang Jangka Panjang }\end{array}$ & 110.000 .000 & 115.000 .000 & 125.000 .000 & 5.000 .000 & 10.000 .000 \\
\hline Jumlah HJ Panjang & 110.000 .000 & 115.000 .000 & 125.000 .000 & 5.000 .000 & 10.000 .000 \\
\hline $\begin{array}{l}\text { Ekuitas } \\
\text { Modal }\end{array}$ & 200.500 .000 & 400.000 .000 & 500.000 .000 & 199.000 .000 & 100.000 .00 \\
\hline Jumlah Ekuitas & 200.500 .000 & 400.000 .000 & 500.000 .000 & 199.500 .000 & 100.000 .000 \\
\hline TOTAL PASIVA & 417.500 .000 & 625.000 .000 & 745.000 .000 & 207.500 .000 & 120.000 .000 \\
\hline
\end{tabular}

Sumber : UD. Aka Jati Jepara Kupang

TABEL 9

RUGI/LABA PERBANDINGAN

PER TAHUN 2012, 2013 DAN 2014

\begin{tabular}{|l|l|l|l|l|l|}
\hline \multicolumn{1}{|c|}{ Keterangan } & Tahun 2012 & \multicolumn{1}{|c|}{ Tahun 2013 } & Tahun 2014 & $\begin{array}{c}\text { Naik/turun } \\
\mathbf{2 0 1 3 - 2 0 1 2}\end{array}$ & $\begin{array}{c}\text { Naik/turun } \\
\mathbf{2 0 1 4 - 2 0 1 3}\end{array}$ \\
\hline Penjualan & 400.000 .000 & 660.000 .000 & 920.000 .000 & 260.000 .000 & 260.000 .000 \\
\hline HPP & 100.000 .000 & 200.000 .000 & 325.000 .000 & 100.000 .000 & 125.000 .000 \\
\hline Laba Kotor & 300.000 .000 & 460.000 .000 & 595.000 .000 & 160.000 .000 & 135.000 .000 \\
\hline Biaya Operasi & 75.000 .000 & 150.000 .000 & 250.000 .000 & 75.000 .000 & 100.000 .000 \\
\hline Laba Operasi & 225.000 .000 & 310.000 .000 & 345.000 .000 & 85.000 .000 & 35.000 .000 \\
\hline $\begin{array}{l}\text { Penghasilan/ beban lain- } \\
\text { lain }\end{array}$ & & & & & \\
\hline Bunga & 75.000 .000 & 140.000 .000 & 195.000 .000 & 65.000 .000 & 55.000 .000 \\
\hline Laba Sebelum Pajak & 150.000 .000 & 170.000 .000 & 150.000 .000 & 20.000 .000 & $(20.000 .000)$ \\
\hline Pajak 15\% & 22.500 .000 & 25.500 .000 & 22.500 .000 & 3.000 .000 & $(3.000 .000)$ \\
\hline Laba Bersih & $\mathbf{1 2 7 . 5 0 0 . 0 0 0}$ & $\mathbf{1 4 4 . 5 0 0 . 0 0 0}$ & $\mathbf{1 2 7 . 5 0 0 . 0 0 0}$ & $\mathbf{1 7 . 0 0 0 . 0 0 0}$ & $\mathbf{( 1 7 . 0 0 0 . 0 0 0 )}$ \\
\hline
\end{tabular}

Sumber: UD. Azka Jati Jepara Kupang

\section{POLITEKNIK NEGERI KUPANG}


1.1 Analisis Perutaran Modal Kerja Modal kerja selalu ada dalam keadaan berputar atau operasi dalam perusahaan selama pe/rusahaan yang bersangkutan dalam keadaan usaha.
Perputaran modal kerja dapat dihitung dengan membandingkan antara penjualan netto dengan aktiva lancar dikurangi hutang lancar.

\section{Analisis Perputaran Modal Kerja}

Tahun 2012

$$
\begin{aligned}
\text { Perputaran Modal Kerja } & =\frac{\text { penjualan neto }}{\text { aktiva lancar-hutang lancar }} \\
& =\frac{400.000 .000}{350.500 .000-107.000 .000} \\
& =\frac{400.000 .000}{243.500 .000}=1,64 \mathrm{kali}
\end{aligned}
$$

Tahun 2013

$$
\begin{aligned}
& \text { Perputaran Modal Kerja }=\frac{\text { penjualan neto }}{\text { aktiva lancar-hutang lancar }} \\
& \qquad=\frac{660.000 .000}{440.000 .000}=1,5 \mathrm{kali}
\end{aligned}
$$

Tahun 2014

$$
\begin{aligned}
\text { Perputaran Modal Kerja } & =\frac{\text { penjualan neto }}{\text { aktiva lancar-hutang lancar }} \\
& =\frac{920.000 .000}{635.000,000-120.000 .000} \\
& =\frac{920.000 .000}{755.000 .000}=1,21 \mathrm{kali}
\end{aligned}
$$

Dari perhitungan diatas menunjukkan bahwa perputaran modal kerja UD. Azka Jati Jepara Kupang yang dicapai pada tahun 2012 sebanyak 1,64 kali. Untuk tahun 2013 sebanyak 1,5 kali sedangkan untuk tahun 2014 sebanyak 1,21 kali. Bila tingkat perputaran modal kerja tersebut

dibandingkan dengan standar pengukuran maka pada tahun 2012 dan 2013 termasuk dalam kriteria tidak baik. Sedangkan pada tahun 2014 tingkat perputaran modal kerja dibandingkan dengan standar pengukuran maka pada tahun 2014 termasuk dalam kriteria cukup baik. 
Tabel 10

Hubungan antara Rasio Modal Kerja dan Rasio Profitabilitas

\begin{tabular}{|c|l|r|r|r|c|c|}
\hline Tahun & \multicolumn{1}{|c|}{ Modal Kerja } & PMK & Kriteria & $\begin{array}{c}\text { Rasio } \\
\text { Profitabilitas }\end{array}$ & Nilai & Kriteria \\
\hline 2012 & Perputaran Kas & $2,6 \mathrm{kali}$ & Cukup baik & ROI & $359 \%$ & Sangat baik \\
\hline & Perputaran Piutang & $7,5 \mathrm{kali}$ & Sangat baik & & & \\
\hline & Perputaran Persediaan & $2,48 \mathrm{kali}$ & Cukup baik & & & \\
\hline 2013 & Perputaran Kas & $2,64 \mathrm{kali}$ & Cukup baik & ROI & $272 \%$ & Sangat baik \\
\hline & Perputaran Piutang & $12,5 \mathrm{kali}$ & Sangat baik & & & \\
\hline & Perputaran Persediaan & $2,95 \mathrm{kali}$ & Cukup baik & & & Sangat baik \\
\hline & Perputaran Kas & $3,50 \mathrm{kali}$ & Sangat baik & ROI & $201 \%$ & \\
\hline & Perputaran Piutang & $15,9 \mathrm{kali}$ & Sangat baik & & & \\
\hline
\end{tabular}

Sumber: data diolah oleh penulis pada tahun 2015

Tabel diatas merupakan tabel perhitungan perbandingan modal kerja dan rasio Profitabilitas selama tahun 2012-2014 yang menunjukan bahwa modal kerja dan rasio profitabilitas perusahaan berfluktuasi

\section{Tabel 15}

dari tahun ke tahun.

Perputaran modal kerja pada UD. Azka Jati Jepara Kupang dari tahun 2012-2014 dapat dilihat dalam perhitungan pada tabel dibawah ini:

UD. Azka Jati Jepara Kupang

Perhitungan Perputaran Modal Kerja

\begin{tabular}{|l|l|l|l|l|l|l|}
\hline Tahun & $\begin{array}{l}\text { Penjualan } \\
\text { neto }\end{array}$ & $\begin{array}{l}\text { Aktiva } \\
\text { lancar }\end{array}$ & $\begin{array}{l}\text { Hutang } \\
\text { lancar }\end{array}$ & $\begin{array}{l}\text { Perputaran } \\
\text { modal } \\
\text { kerja }\end{array}$ & Standar & Kriteria \\
\hline 2012 & 400.000 .000 & 350.500 .000 & 107.000 .000 & 1,64 kali & $<2$ kali & Cukup baik \\
\hline 2013 & 660.000 .000 & 550.000 .000 & 110.000 .000 & 1,5 kali & $<2$ kali & Cukup baik \\
\hline 2014 & 920.000 .000 & 635.000 .000 & 120.000 .000 & 1,21 kali & $<2$ kali & Cukup baik \\
\hline
\end{tabular}

\section{Sumber: data diolah oleh penulis pada tahun 2015}

Berdasarkan perhitungan tabel diatas menunjukan bahwa perputaran modal kerja pada UD. Azka Jati Jepara Kupang yang dicapai pada tahun 2012 adalah 1,64 kali yang berarti dana yang tertanam dalam modal kerja perputaran rata-rata 1,5 kali dalam setahun. Untuk tahun 2013 tingkat perputaran modal kerja
1,5 kali yang berarti modal yang tertanam dalam modal kerja perputaran rata-rata 1,64 kali dalam setahun. Dan untuk tahun 2014 tingkat perputaran modal kerja 1,21 kali yang berarti modal yang tertanam dalam modal kerja perputaran rata-rata 1,5 kali dalam setahun. perputaran modal kerja 
selama 3 tahun dengan menunjukan perputaran modal kerja dalam keadaan kurang sehat.

Bila tingkat perputaran modal kerja tersebut dibandingkan dengan standar pengukuran maka pada tahun 2012-2014 standar perputaran modal kerja yang dicapai dibawah rata-rata yaitu 2 kali. Karena standar perputaran modal kerja yang baik adalah 5 kali. Pada perputaran modal kerja selama 3 tahun dalam penilaian angka 2 menunjukan perputaran modal kerja dalam keadaan kurang sehat.

\section{PENUTUP}

\section{Kesimpulan}

Berdasarkan pembahasan dan analisa yang telah ditemukakan, dapat diambil kesimpulan sebagai berikut:

1. Tingkat perputaran modal kerja yang dicapai oleh UD. Azka Jati Jepara Kupang pada tahun 2012-2014. Pada tahun 2012 perputaran kas 2,6 kali peputaran piutang 7,5 kali dan perputaran persediaan 3,50 kali. Pada tahun 2013 perputaran kas 7,5 kali perputan piutang 12,5 kali dan perputaran persediaan 15,9 kali sedangkan pada tahun 2014 perputaran kas 2,48 kali perputaran piutang 5,95 kali dan perputaran persediaan 2,41 kali. Hal ini menunjukan bahwa modal kerja pada UD. Azka Jati Jepara Kupang belum dapat dikatakan efisien karena perusahaan berfluktuasi dari tahun ke tahun.

2. Tingkat profitabilitas yang dicapai oleh UD. Azka Jati Jepara Kupang pada tahun 2012-2014. Pada tahun 2012 ROI 359\% tahun 2013 272\% sedangkan tahun $2014201 \%$. Hal ini menunjukan bahwa efktifitas dan efisien dalam tingkat profitabilitas pada perusahaan sudah tercapai.

Penilaian perputaran modal kerja dan tingkat profitabilitas yang dicapai oleh UD. Azka Jati Jepara Kupang pada tahun 2012-2014. Pada tahun 2012 perputaran kas 2,6 kali hal ini menunjukan bahwa perputaran kas cukup sehat.

\section{Saran}

Berdasarkan kesimpulan yang telah diuraikan diatas maka ada beberapa saran yang dapat penulis sampaikan sebagai berikut:

1. UD. Azka Jati Jepara Kupang diharapkan dapat meningkatkan tingkat perputaran modal kerja dengan cara meningkatkan perputaran kas, perputaran piutang dan perputaran persediaan. Karena semakin cepat perputaran modal kerja akan berpengaruh 
positif terhadap profitabilitas perusahaan.

2. Perusahaan disarankan untuk tetap mempertahankan tingkat profitabilitasnya, karena dengan meningkatnya tingkat profitabilitas pada perusahaan tersebut maka akan mengurangi hutang jangka pendek dalam perusahaan.

\section{DAFTAR PUSTAKA}

Alwi, dkk. 2005. Kamus Besar Bahasa Indonesia. Departemen Pendidikan Nasional. Balai Pustaka: Jakarta.

Arikunto dan Suharsimi. 2002. Prosedur

Penelititan Suatu Pendekatan

Praktek. Penerbit Rineka Cipta Indonesia: Yogyakarta.

Baridwan, Zaky. 2004. Intermediate

Acounting. Edisi 8. Penerbit BPFE:

Yogyakarta.

Djarwanto. 2005. Pokok-pokok Analisa

Laporan Keuangan. BPFE:

Yogyakarta.
Kasmir. 2008. Analisis Laporan Keuangan. Raja Grafindo Persada: Jakarta.

Kuncoro. 2003. Prosedur Penelititan Suatu Pendekatan Praktek. Penerbit Rineka Cipta Indonesia: Yogyakarta.

Kepmen BUMN No. 1000 Tahun 2001

Munawir, S. 2002. Analisis Laporan Keuangan. Edisi Keempat Liberty: Yogyakarta.

2004. Analisis Laporan

Keuangan. Edisi Keempat Liberty: Yogyakarta. 2007. Analisis Laporan Keuangan. Edisi Keempat Liberty: Yogyakarta.

Riyanto. 2000. Dasar-Dasar Pembelanjaan Perusahaan. Edisi Keempat Cetakan Ketujuh. Yogyakarta: BFFE. 2001

Dasar-Dasar Pembelanjaan Perusahaan. Edisi Keempat Cetakan Ketujuh. Yogyakarta: BFFE.

Syahrul. 2000. Akuntansi Manajemen. Rineka Cipta: Jakarta. 